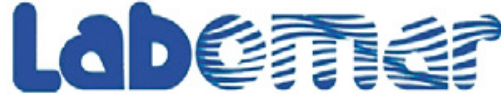

Arquivos de Ciências do Mar

\section{THE IMPORTANCE OF GEARÁ STATE TO THE BRAZILIAN MARINE ORNAMENTAL FISH EXPORTS}

\section{A importância do estado do Ceará para as exportações brasileiras de peixes ornamentais marinhos}

\author{
Lívio Moreira de Gurjão', Tito Monteiro da Cruz Lotufo² \\ ${ }^{1}$ Analista Ambiental, Núcleo de Pesca da Superintendência do Ibama no Ceará, Av. Visconde do Rio Branco, 3900, \\ Joaquim Távora, CEP 60055-172, Fortaleza-CE, Brasil. e-mail: livio.gurjao@gmail.com \\ ${ }^{2}$ Professor Doutor, Instituto Oceanográfico da Universidade de São Paulo, Praça do Oceanográfico, 191, Sala 149B, \\ Butantã, CEP 05508120, São Paulo-SP, Brasil. E-mail: tmlotufo@usp.br
}

\begin{abstract}
Brazil is one of the main suppliers of marine aquarium fish in the world and Ceará state is the most relevant trader in the country. However, there is a paucity of updated information regarding the activity, which is crucial for the sustainable exploitation of those organisms. Thus, the present work provides the most recent data related to Brazilian and, more specifically, Ceará state marine aquarium fish exports, by means of the analysis of information from 420,871 authorizations of export issued by Brazilian environmental authorities in the last 10 years. Results corroborate the relevant participation of Ceará state in the Brazilian marine ornamental fish trade, but also show a substantial decline of exports along the last decade. Sixteen species were the most abundant and more frequently traded. Unsurprisingly, pomacanthids were the most important exported fish, and probably more than 283,525 individuals were wild-caught in an almost 10-years interval. Current Brazilian exports are mainly driven to Asian countries and seasonal displacements of the Intertropical Convergence Zone (ITCZ) seems to influence ornamental fish harvesting in Ceará state, impacting significantly the Brazilian performance in the trade.
\end{abstract}

Keywords: Marine ornamental species, marine aquarium fish, marine aquarium trade, Brazilian exports, Ceará state.

Recebido em: 31/05/2017

Aprovado em: 04/05/2018

Publicado online em: 05/09/2018 


\section{RESUMO}

O Brasil é um dos principais fornecedores mundiais de peixes ornamentais marinhos e Ceará é o estado exportador de maior relevância no país. Entretanto, existe uma carência de informações atualizadas sobre a atividade, o que é crucial para a explotação sustentável desses organismos. Assim, o presente trabalho fornece os dados mais recentes em relação às exportações brasileiras e, mais especificamente, cearenses de peixes ornamentais marinhos, por meio da análise de informações contidas em 420.871 autorizações de exportação emitidas pelas autoridades ambientais brasileiras nos últimos 10 anos. Os resultados corroboram a relevante paraticipação do estado do Ceará nas exportações nacionais de peixes ornamentais marinhos, mas também mostram um declínio substancial dessa atividade ao longo da última década. Dezesseis espécies foram as mais abundantes e frequentes tanto nas exportações brasileiras quanto nas cearenses. Não surpreendentemente, os pomacantídeos foram os peixes mais importantes comercializados, $e$ provavelmente mais de 283.525 indivíduos foram capturados na natureza em um intervalo de aproximadamente 10 anos. Atualmente as exportações brasileiras são direcionadas principalmente para os países asiáticos e deslocamentos sazonais da Zona de Convergência Intertropical (ZCIT) parecem interferir na coleta de peixes ornamentais no Ceará, impactando significativamente a performance brasileira no mercado.

Palavras-chaves: Espécies ornamentais marinhas, peixes de aquário marinho, aquariofilia marinha, exportações brasileiras, estado do Ceará.

\section{INTRODUCTION}

Marine ornamental trade is a global multi-million dollar industry, involving at least 45 countries and the collection of 30 million fish specimens, belonging to 125 different families, and 1,800 species (Wood, 2001; Tissot et al., 2010; Stevenson et al., 2011; Rhyne et al., 2014).

Brazil is considered one of the main suppliers of the marine aquarium market (Wood, 2001; Bruckner, 2005; Rhyne et al., 2012) and, like in the other exporting countries, the great majority of the exported specimens is wild harvested. Therefore, there are some concerns regarding (Gasparini et al., 2005; Nottingham et al., 2005a).

Ceará state is the leading Brazilian marine aquarium fish exporter (Monteiro-Neto et al., 2003; Nottingham et al., 2005b) and the regional data concerning exploitation have been used as reference for the establishment of norms to regulate the ornamental trade in the whole country (Nottingham et al., 2005a).

Hence, given the importance of updated information to guide the implementation of policies and rules aiming the sustainable exploitation of marine ornamentals in Brazil, it is not only crucial to fulfill the lack of basic knowledge concerning life history, reproduction and population dynamics of targeted species (Nottingham et al., 2000; Nottingham et al., 2003; Gasparini et al., 2005; Nottingham et al., 2005b; Feitosa et al., 2015), but also the paucity of data regarding exports in the last decade must be repaired - since the most recent published statistics regarding Brazilian exports of marine aquarium fish were related to 2006 and 2007 (IBAMA, 2008).

Therefore, the present work provides updated information regarding Brazilian marine ornamental fish exports, outstanding the importance of Ceará state to the 
international commerce, and offers a better evaluation of the dynamic aspect of the trade, identifying changes that have been occurring in the activity along the last decade.

\section{MATERIALS AND METHODS}

Information obtained from 420,871 authorizations of export, issued by the Brazilian Institute for the Environment and Renewable Natural Resources - IBAMA, was used in the current analysis. These data referred exclusively to the international market from January 2006 to August 2015, and provided information regarding the number of authorizations issued, participation of Ceará state in the Brazilian exports, species and quantities traded, as well as buyer countries.

In order to estimate how important each species is to the trade, they were analyzed concerning two different criteria: frequency of occurrence - FO (the relative proportion of years in which a particular species is exported) and numerical abundance - \% Num (the percentage of the total number of all specimens represented by individuals of a particular species). Then, the number of exported specimens and the variety of species commerced were evaluated to assess the development of the marine ornamental fish trade along almost 10 years of monitoring. Average US Dollar exchange rate was used investigate the economic scenery faced by exporters in the last decade.

Additionally, exports were examined with regards to seasonal variations (from January 2006 to December 2014), and the authorizations issuing dates were distributed amongst the four seasons in the Northern Hemisphere, in accordance with the Earth's rotation axis and its orbital plane: Winter (December 21 - March 19), Spring (March 20 June 20), Summer (June 21 - September 21) and Fall (September 22 - December 20). Oneway ANOVA and Tukey HSD were used to investigate pairwise differences among seasons, by using PAST software (Hammer et al., 2001).

In general, scientific names were kept as originally written in the spreadsheets, after checking for valid species and natural distributions (Froese \& Pauly, 2017). However, in a very few cases names had to be updated according to the most recent literature and one of them was excluded from the analysis due to nonexistence of the species recorded.

\section{RESULTS}

During the analyzed period, the Brazilian international marine ornamental trade was represented by seven exporting states (Ceará, Bahia, Espírito Santo, Pará, Pernambuco, Rio de Janeiro and São Paulo) and the former was the most relevant given its highest percentage of exports (Figure 1) - $\mathrm{x}=74 \%$, sd $=13 \%$ - and the number of exported specimens, despite a notable decrease in the activity along the last decade (Figure 2).

Data analysis revealed that 136 species were exported from January 2006 to August 2015 in Brazil and that 31 of them were the most often (FO =100\%). Otherwise, the trade represented exclusively by Ceará state involved 122 species and $\mathrm{FO}=100 \%$ was observed for 28 species (Table I). 
Figure 1 - Participation of Ceará state (CE) in the Brazilian (BR) exports of marine aquarium fish. *Data from 2015 were available solely until the month of August.

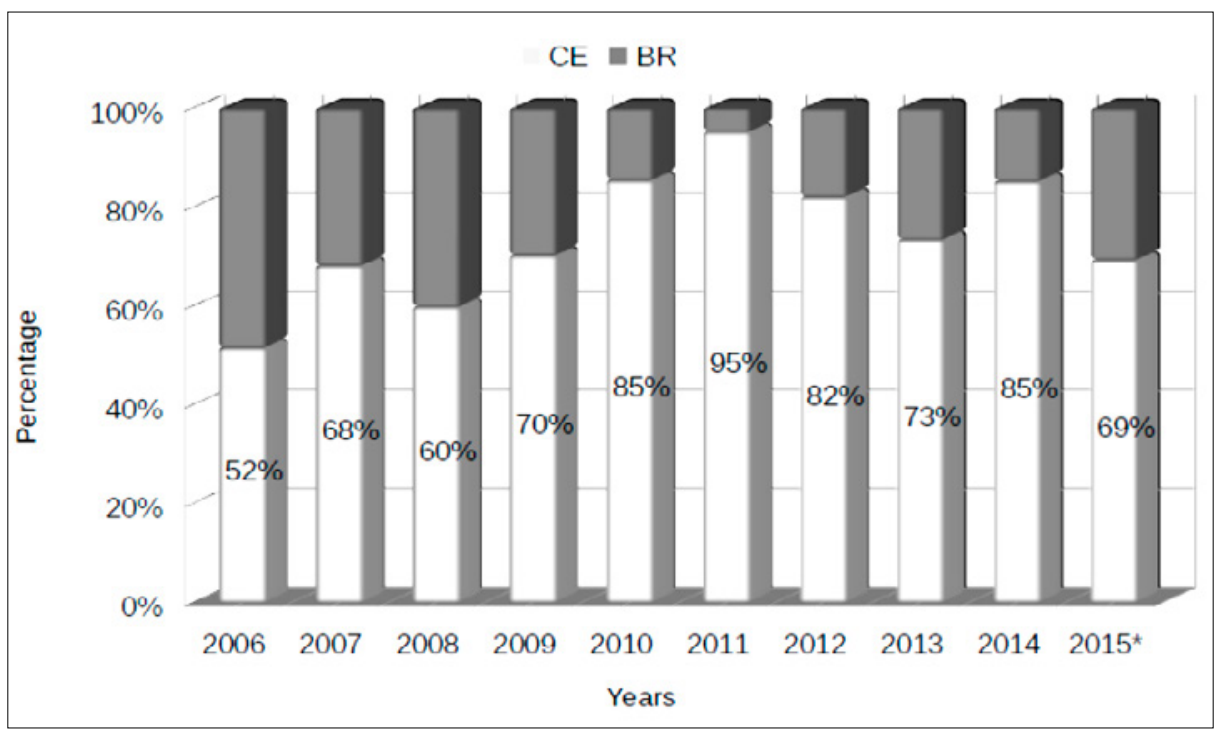

Figure 2 - Exports of marine ornamental fish in Brazil (BR) and Ceará state (CE) along the last decade. *Data from 2015 were available solely until the month of August.

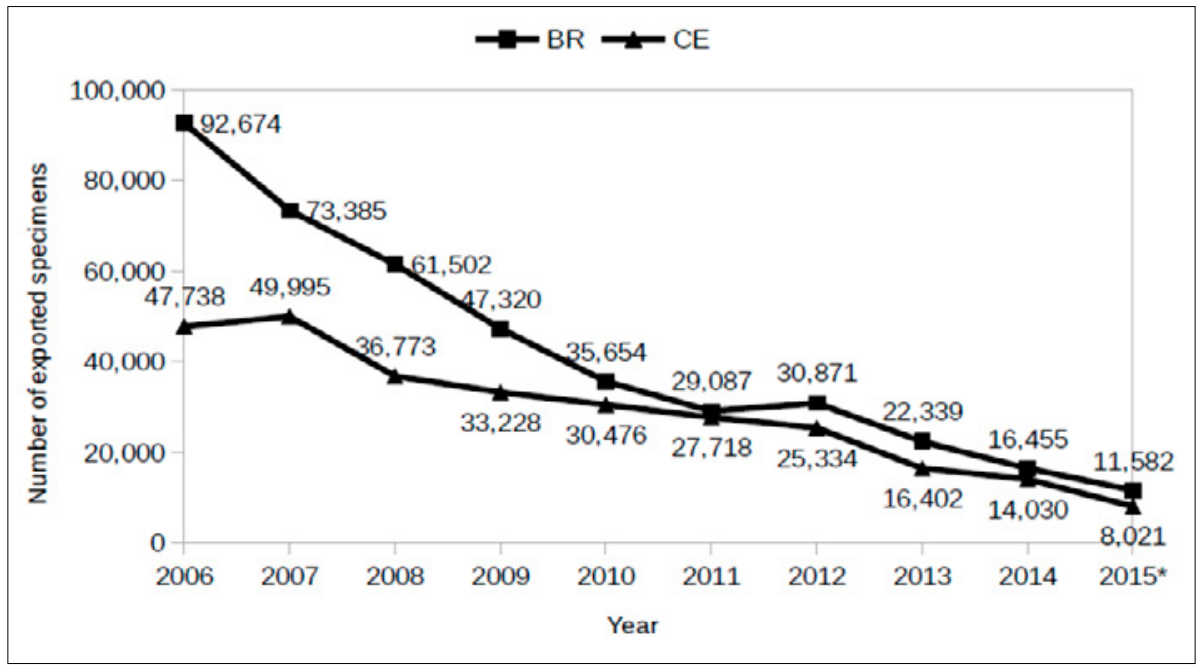

Table I - Marine ornamental fish exported in Brazil and Ceará state, from 2006 to August 2015. \%Num - numerical abundance and FO - frequency of occurrence.

\begin{tabular}{lccrrrr}
\hline \multicolumn{1}{c}{ Species } & \multicolumn{2}{c}{ Brazil } & \multicolumn{3}{c}{ Ceará state } \\
& Subtotal & \%Num & FO & Subtotal & $\%$ Num & FO \\
\hline Abudefduf saxatilis (Linnaeus, 1758) & 560 & 0.13 & 20 & 233 & 0.08 & 20 \\
Acanthostracion polygonius Poey, 1876 & 123 & 0.03 & 60 & 91 & 0.03 & 40 \\
Acanthostracion quadricornis (Linnaeus, 1758) & 122 & 0.03 & 80 & 92 & 0.03 & 70 \\
Acanthurus bahianus Castelnau, 1855 & 3645 & 0.87 & 100 & 1,711 & 0.59 & 100 \\
Acanthurus chirurgus (Bloch, 1787) & 515 & 0.12 & 80 & 155 & 0.05 & 60 \\
Acanthurus coeruleus Bloch \& Schneider, 1801 & 22,305 & 5.30 & 100 & 13,283 & 4.58 & 100 \\
Achirus lineatus (Linnaeus, 1758) & 380 & 0.09 & 70 & 39 & 0.01 & 30 \\
Alphestes afer (Bloch, 1793) & 333 & 0.08 & 90 & 301 & 0.10 & 80 \\
Aluterus schoepfi (Walbaum, 1792) & 243 & 0.06 & 20 & 206 & 0.07 & 20 \\
\hline
\end{tabular}


(continuation Table I)

\begin{tabular}{|c|c|c|c|c|c|c|}
\hline Aluterus scriptus (Osbeck, 1765) & 68 & 0.02 & 40 & 17 & 0.01 & 30 \\
\hline Amblycirrhitus pinos (Mowbray, 1927) & 998 & 0.24 & 100 & 516 & 0.18 & 100 \\
\hline Anisotremus surinamensis (Bloch, 1791) & 118 & 0.03 & 20 & 88 & 0.03 & 20 \\
\hline Anisotremus virginicus (Linnaeus, 1758) & 6370 & 1.51 & 100 & 2,358 & 0.81 & 100 \\
\hline Antennarius striatus (Shaw, 1794) & 827 & 0.20 & 100 & 482 & 0.17 & 90 \\
\hline Apogon americanus Castelnau, 1855 & 2761 & 0.66 & 80 & 1.320 & 0.46 & 70 \\
\hline Apogon pseudomaculatus Longley, 1932 & 1275 & 0.30 & 50 & 277 & 0.10 & 30 \\
\hline Archosargus rhomboidalis (Linnaeus, 1758) & 20 & 0.00 & 30 & 2 & 0.00 & 10 \\
\hline Aulostomus strigosus Wheeler, 1955 & 13 & 0.00 & 20 & 10 & 0.00 & 10 \\
\hline Bathygobius soporator (Valenciennes, 1837) & 234 & 0.06 & 30 & 216 & 0.07 & 20 \\
\hline Batrachoides surinamensis (Bloch \& Schneider, 1801) & 239 & 0.06 & 80 & 200 & 0.07 & 80 \\
\hline Bodianus pulchellus (Poey, 1860) & 12,601 & 2.99 & 100 & 4,674 & 1.61 & 80 \\
\hline Bodianus rufus (Linnaeus, 1758) & 11,710 & 2.78 & 100 & 5,998 & 2.07 & 100 \\
\hline Bothus lunatus (Linnaeus, 1758) & 104 & 0.02 & 70 & 49 & 0.02 & 50 \\
\hline Bothus ocellatus (Agassiz, 1831) & 147 & 0.03 & 70 & 28 & 0.01 & 40 \\
\hline Calamus pennatula Guichenot, 1868 & 1370 & 0.33 & 30 & 184 & 0.06 & 10 \\
\hline Cantherhines macrocerus (Hollard, 1853) & 354 & 0.08 & 100 & 144 & 0.05 & 100 \\
\hline Cantherhines pullus (Ranzani, 1842) & 1167 & 0.28 & 100 & 978 & 0.34 & 100 \\
\hline Canthigaster figueiredoi Moura \& Castro, 2002 & 594 & 0.14 & 70 & 350 & 0.12 & 70 \\
\hline Centropyge aurantonotus Burgess, 1974 & 20,767 & 4.93 & 100 & 10,783 & 3.72 & 90 \\
\hline Cephalopholis fulva (Linnaeus, 1758) & 52 & 0.01 & 10 & - & - & - \\
\hline Chaetodipterus faber (Broussonet, 1782) & 2999 & 0.71 & 100 & 2,267 & 0.78 & 100 \\
\hline Chaetodon ocellatus Bloch, 1787 & 3532 & 0.84 & 100 & 2,833 & 0.98 & 100 \\
\hline Chaetodon sedentarius Poey, 1860 & 1924 & 0.46 & 100 & 1,583 & 0.55 & 100 \\
\hline Chaetodon striatus Linnaeus, 1758 & 5118 & 1.22 & 100 & 3,598 & 1.24 & 100 \\
\hline Chilomycterus antennatus (Cuvier, 1816) & 3571 & 0.85 & 100 & 2,410 & 0.83 & 100 \\
\hline Chilomycterus antillarum Jordan \& Rutter, 1897 & 572 & 0.14 & 40 & 433 & 0.15 & 40 \\
\hline Chromis multilineata (Guichenot, 1853) & 569 & 0.14 & 50 & 487 & 0.17 & 40 \\
\hline $\begin{array}{l}\text { Clepticus brasiliensis Heiser, Moura \& } \\
\text { Robertson, } 2000\end{array}$ & 12 & 0.00 & 10 & - & - & - \\
\hline Conodon nobilis (Linnaeus, 1758) & 62 & 0.01 & 20 & - & - & - \\
\hline Coryphopterus glaucofraenum Gill, 1863 & 2341 & 0.56 & 70 & 2,337 & 0.81 & 70 \\
\hline Cosmocampus albirostris (Kaup, 1856) & 4 & 0.00 & 10 & - & - & - \\
\hline Chilomycterus spinosus (Linnaeus, 1758) & 1214 & 0.29 & 90 & 1,261 & 0.44 & 90 \\
\hline Dactylopterus volitans (Linnaeus, 1758) & 1560 & 0.37 & 100 & 654 & 0.23 & 100 \\
\hline Diodon holacanthus Linnaeus, 1758 & 1655 & 0.39 & 80 & 1,632 & 0.56 & 80 \\
\hline Diodon hystrix Linnaeus, 1758 & 6185 & 1.47 & 100 & 5,869 & 2.03 & 100 \\
\hline Diplectrum formosum (Linnaeus, 1766) & 572 & 0.14 & 10 & 550 & 0.19 & 10 \\
\hline Diplectrum radiale (Quoy \& Gaimard, 1824) & 30 & 0.01 & 10 & - & - & - \\
\hline Doratonotus megalepis Günther, 1862 & 44 & 0.01 & 40 & 14 & 0.00 & 30 \\
\hline Dules auriga Cuvier, 1829 & 44 & 0.01 & 10 & 15 & 0.01 & 10 \\
\hline Echeneis naucrates Linnaeus, 1758 & 237 & 0.06 & 60 & 214 & 0.07 & 30 \\
\hline Fistularia tabacaria Linnaeus, 1758 & 75 & 0.02 & 10 & 75 & 0.03 & 10 \\
\hline Gobiesox strumosus Cope, 1870 & 480 & 0.11 & 80 & 737 & 0.25 & 70 \\
\hline Gymnachirus nudus Kaup, 1858 & 12 & 0.00 & 40 & 3 & 0.00 & 30 \\
\hline Gymnothorax funebris Ranzani, 1839 & 1308 & 0.31 & 100 & 1,068 & 0.37 & 100 \\
\hline Gymnothorax miliaris (Kaup, 1856) & 1849 & 0.44 & 100 & 1,361 & 0.47 & 100 \\
\hline Gymnothorax moringa (Cuvier, 1829) & 189 & 0.04 & 90 & 156 & 0.05 & 80 \\
\hline Gymnothorax ocellatus Agassiz, 1831 & 122 & 0.03 & 80 & 117 & 0.04 & 70 \\
\hline Gymnothorax vicinus (Castelnau, 1855) & 268 & 0.06 & 80 & 262 & 0.09 & 80 \\
\hline Haemulon steindachneri (Jordan \& Gilbert, 1882) & 147 & 0.03 & 30 & 147 & 0.05 & 30 \\
\hline Halichoeres bivittatus (Bloch, 1791) & 193 & 0.05 & 60 & 156 & 0.05 & 60 \\
\hline Halichoeres brasiliensis (Bloch, 1791) & 934 & 0.22 & 100 & 589 & 0.20 & 100 \\
\hline Halichoeres dimidiatus (Agassiz, 1831) & 4396 & 1.04 & 100 & 2,184 & 0.75 & 100 \\
\hline Halichoeres penrosei Starks, 1913 & 1107 & 0.26 & 100 & 772 & 0.27 & 100 \\
\hline Halichoeres poeyi (Steindachner, 1867) & 271 & 0.06 & 80 & 226 & 0.08 & 70 \\
\hline
\end{tabular}


(continuation Table I)

\begin{tabular}{|c|c|c|c|c|c|c|}
\hline Heteropriacanthus cruentatus (Lacepède, 1801) & 30 & 0.01 & 40 & 20 & 0.01 & 30 \\
\hline Hippocampus erectus Perry, 1810 & 4915 & 1.17 & 70 & 3,665 & 1.27 & 70 \\
\hline Hippocampus reidi Ginsburg, 1933 & 23,274 & 5.53 & 100 & 7,572 & 2.61 & 100 \\
\hline Holacanthus ciliaris (Linnaeus, 1758) & 107,453 & 25.53 & 100 & 90,728 & 31,32 & 100 \\
\hline Holacanthus tricolor (Bloch, 1795) & 27,881 & 6.62 & 100 & 18,029 & 6.22 & 100 \\
\hline Holocentrus adscensionis (Osbeck, 1765) & 56 & 0.01 & 70 & 50 & 0.02 & 50 \\
\hline Kyphosus incisor (Cuvier, 1831) & 12 & 0.00 & 10 & 6 & 0.00 & 10 \\
\hline Kyphosus sectatrix (Linnaeus, 1758) & 460 & 0.11 & 20 & - & - & - \\
\hline Labrisomus nuchipinnis (Quoy \& Gaimard, 1824) & 225 & 0.05 & 70 & 219 & 0.08 & 70 \\
\hline Lactophrys trigonus (Linnaeus, 1758) & 974 & 0.23 & 100 & 845 & 0.29 & 100 \\
\hline Lagocephalus laevigatus (Linnaeus, 1766) & 6 & 0.00 & 10 & - & - & - \\
\hline Micropogonias furnieri (Desmarest, 1823) & 10 & 0.00 & 10 & - & - & - \\
\hline Mulloidichthys martinicus (Cuvier, 1829) & 6 & 0.00 & 10 & 6 & 0.00 & 10 \\
\hline Mullus argentinae Hubbs \& Marini, 1933 & 18 & 0.00 & 20 & 3 & 0.00 & 10 \\
\hline Muraena pavonina Richardson, 1845 & 579 & 0.14 & 70 & 521 & 0.18 & 70 \\
\hline Myrichthys breviceps (Richardson, 1848) & 29 & 0.01 & 60 & 15 & 0.01 & 50 \\
\hline Myrichthys ocellatus (Lesueur, 1825) & 317 & 0.08 & 90 & 189 & 0.07 & 90 \\
\hline Myripristis jacobus Cuvier, 1829 & 287 & 0.07 & 50 & 219 & 0.08 & 50 \\
\hline Odontoscion dentex (Cuvier, 1830) & 10 & 0.00 & 10 & - & - & - \\
\hline Ogcocephalus notatus (Valenciennes, 1837) & 3 & 0.00 & 10 & - & - & - \\
\hline Ogcocephalus vespertilio (Linnaeus, 1758) & 3425 & 0.81 & 100 & 2,772 & 0.96 & 100 \\
\hline Oligoplites saliens (Bloch, 1793) & 7 & 0.00 & 20 & 5 & 0.00 & 10 \\
\hline Ophioblennius trinitatis Miranda Ribeiro, 1919 & 3034 & 0.72 & 80 & 1,933 & 0.67 & 70 \\
\hline Orthopristis ruber (Cuvier, 1830) & 16 & 0.00 & 20 & - & - & - \\
\hline Parablennius marmoreus (Poey, 1876) & 1189 & 0.28 & 40 & 678 & 0.23 & 40 \\
\hline Parablennius pilicornis (Cuvier, 1829) & 1243 & 0.30 & 50 & 571 & 0.20 & 50 \\
\hline Paraclinus rubicundus (Starks, 1913) & 54 & 0.01 & 50 & 24 & 0.01 & 40 \\
\hline Paranthias furcifer (Valenciennes, 1828) & 193 & 0.05 & 50 & 73 & 0.03 & 40 \\
\hline Pareques acuminatus (Bloch \& Schneider, 1801) & 2696 & 0.64 & 100 & 1,619 & 0.56 & 100 \\
\hline Pempheris schomburgki Müller \& Troschel, 1848 & 43 & 0.01 & 10 & 3 & 0.00 & 10 \\
\hline Phaeoptyx pigmentaria (Poey, 1860) & 70 & 0.02 & 20 & 25 & 0.001 & 20 \\
\hline Plectrypops retrospinis (Guichenot, 1853) & 254 & 0.06 & 30 & 22 & 0.001 & 20 \\
\hline Pomacanthus arcuatus (Linnaeus, 1758) & 29,547 & 7.02 & 100 & 21,723 & 7.50 & 100 \\
\hline Pomacanthus paru (Bloch, 1787) & 70,010 & 16.63 & 100 & 52,463 & 18,11 & 100 \\
\hline Pomadasys corvinaeformis (Steindachner, 1868) & 7 & 0.00 & 10 & 5 & 0.00 & 10 \\
\hline Porichthys porosissimus (Cuvier, 1829) & 33 & 0.01 & 40 & 33 & 0.01 & 40 \\
\hline Prionotus nudigula Ginsburg, 1950 & 150 & 0.04 & 60 & 102 & 0.04 & 60 \\
\hline Prionotus punctatus (Bloch, 1793) & 10 & 0.00 & 10 & - & - & - \\
\hline Rypticus bitrispinus (Mitchill, 1818) & 48 & 0.01 & 20 & 10 & 0.00 & 10 \\
\hline Rypticus saponaceus (Bloch \& Schneider, 1801) & 127 & 0.03 & 30 & 101 & 0.03 & 30 \\
\hline Scarus zelindae Moura, Figueiredo \& Sazima, 2001 & 95 & 0.02 & 60 & 76 & 0.03 & 50 \\
\hline Scorpaena brasiliensis Cuvier, 1829 & 98 & 0.02 & 60 & 49 & 0.02 & 50 \\
\hline Scorpaena isthmensis Meek \& Hildebrand, 1928 & 74 & 0.02 & 50 & 191 & 0.07 & 50 \\
\hline Scorpaena plumieri Bloch, 1789 & 20 & 0.00 & 40 & 12 & 0.00 & 20 \\
\hline Selene vomer (Linnaeus, 1758) & 2500 & 0.59 & 80 & 2,231 & 0.77 & 70 \\
\hline Serranus baldwini (Evermann \& Marsh, 1899) & 694 & 0.16 & 90 & 570 & 0.20 & 60 \\
\hline Serranus flaviventris (Cuvier, 1829) & 289 & 0.07 & 90 & 220 & 0.08 & 90 \\
\hline Serranus phoebe Poey, 1851 & 79 & 0.02 & 20 & 55 & 0.02 & 10 \\
\hline Sparisoma amplum (Ranzani, 1841) & 89 & 0.02 & 30 & 45 & 0.02 & 30 \\
\hline Sparisoma axillare (Steindachner, 1878) & 30 & 0.01 & 20 & - & - & - \\
\hline Sparisoma frondosum (Agassiz, 1831) & 19 & 0.00 & 30 & 14 & 0.00 & 30 \\
\hline Sparisoma radians (Valenciennes, 1840 ) & 126 & 0.03 & 40 & 16 & 0.01 & 30 \\
\hline Sphoeroides greeleyi Gilbert, 1900 & 43 & 0.01 & 20 & - & - & - \\
\hline Sphoeroides spengleri (Bloch, 1785) & 352 & 0.08 & 60 & 146 & 0.05 & 60 \\
\hline Sphoeroides testudineus (Linnaeus, 1758) & 26 & 0.01 & 30 & 3 & 0.00 & 10 \\
\hline Stegastes fuscus (Cuvier, 1830) & 133 & 0.03 & 60 & 105 & 0.04 & 60 \\
\hline
\end{tabular}


(continuation Table I)

\begin{tabular}{|c|c|c|c|c|c|c|}
\hline Stegastes pictus (Castelnau, 1855) & 754 & 0.18 & 80 & 417 & 0.14 & 80 \\
\hline Stegastes uenfi Novelli, Nunan \& Lima, 2000 & 110 & 0.03 & 60 & 100 & 0.03 & 50 \\
\hline Stegastes variabilis (Castelnau, 1855) & 550 & 0.13 & 90 & 474 & 0.16 & 90 \\
\hline Stephanolepis hispidus (Linnaeus, 1766) & 20 & 0.00 & 10 & 20 & 0.01 & 10 \\
\hline Stephanolepis setifer (Bennett, 1831) & 8 & 0.00 & 10 & 4 & 0.00 & 10 \\
\hline Stygnobrotula latebricola Böhlke, 1957 & 62 & 0.01 & 80 & 31 & 0.01 & 40 \\
\hline Synodus foetens (Linnaeus, 1766) & 571 & 0.14 & 20 & 569 & 0.20 & 20 \\
\hline Synodus intermedius (Spix \& Agassiz, 1829) & 192 & 0.05 & 20 & 180 & 0.06 & 20 \\
\hline Synodus synodus (Linnaeus, 1758) & 20 & 0.00 & 20 & 12 & 0.00 & 10 \\
\hline Thalassoma noronhanum (Boulenger, 1890) & 774 & 0.18 & 100 & 678 & 0.23 & 100 \\
\hline Thalassophryne montevidensis (Berg, 1893) & 11 & 0.00 & 20 & 10 & 0.00 & 10 \\
\hline Thalassophryne nattereri Steindachner, 1876 & 95 & 0.02 & 40 & 39 & 0.01 & 40 \\
\hline Trachinocephalus myops (Forster, 1801) & 201 & 0.05 & 10 & 181 & 0.06 & 10 \\
\hline Upeneus parvus Poey, 1852 & 193 & 0.05 & 40 & 56 & 0.02 & 40 \\
\hline Xyrichthys novacula (Linnaeus, 1758) & 273 & 0.06 & 60 & 121 & 0.04 & 60 \\
\hline Xyrichthys splendens Castelnau, 1855 & 56 & 0.01 & 30 & 46 & 0.02 & 30 \\
\hline Total & 420,869 & 100 & - & 289,715 & 100 & - \\
\hline
\end{tabular}

Even analyzing the same database, the numbers presented in Table I are slightly different from those reported by IBAMA (2008) due to continuous updates along the years, and, so, information presented here shall be more trustworthy.

It is important to notice that some names in the original dataset had to be modified: two specimens named Muraena trigonus were excluded from the analysis, since the species does not exist, and Halichoeres cyanocephalus (Bloch, 1791) and Halichoeres maculipinna (Müller \& Troschel, 1848) were replaced, respectively, by Halichoeres dimidiatus (Agassiz, 1831) and Halichoeres penrosei Starks, 1913 in accordance with the most recent taxonomic reviews (Rocha \& Rosa, 2001; Rocha, 2004). Chilomycterus spinosus (Linnaeus, 1758) was also substituted for Cychlichthys spinosus (Linnaeus, 1758), according to valid synonyms (Froese \& Pauly, 2017).

Despite the great number of exploited species, there were expressive reductions concerning the variety of species exported along the monitored period (Figure 3).

Figure 3 - Number of exported species in Brazil (BR) and Ceará state (CE), from 2006 to August 2015.

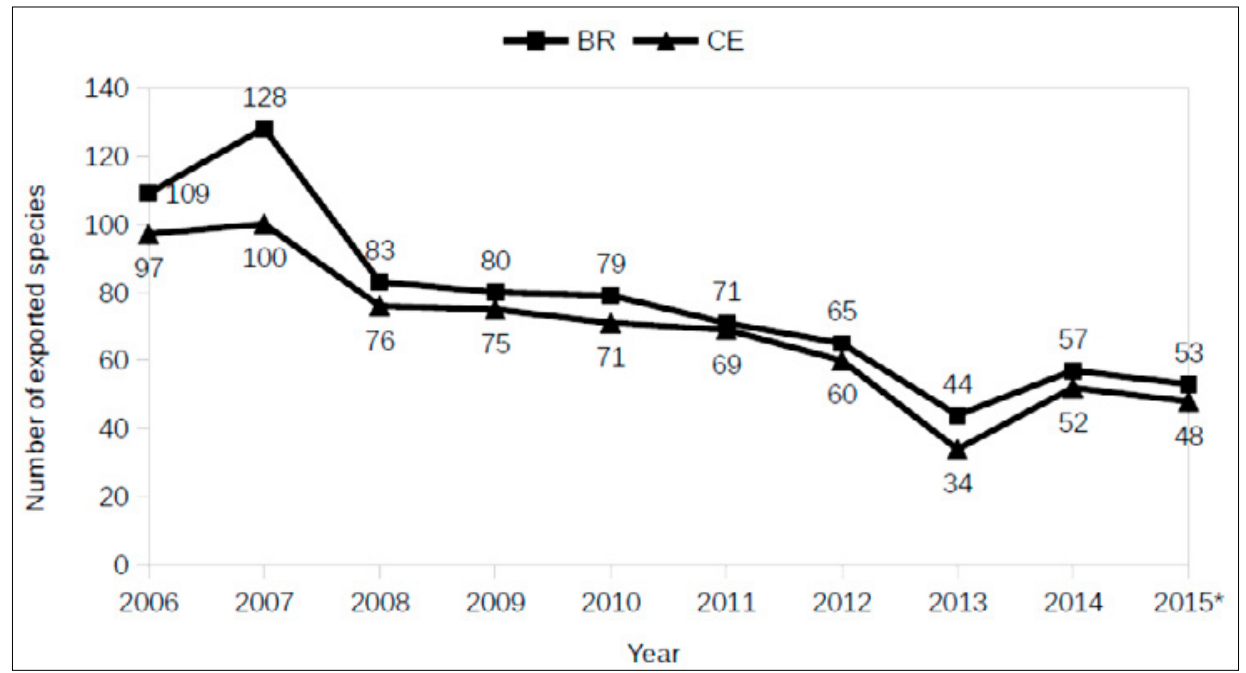


It must be highlighted that both the decreasing number of individuals (Figure 2) and the declining variety of traded species (Figure 3) occurred in spite of the exporting stimulus caused by favorable US Dollar exchange rates from 2011 to 2015 (Figure 4).

Sixteen species were the most numerically abundant, representing more than $80 \%$ of the exported individuals (Figure 5), and most of them also achieved FO $=100 \%$. The other species represented less than $1 \%$ of the trade volume, each.

Figure 4 - Average American Dollar exchange rate in Brazil from 2006 to 2015.

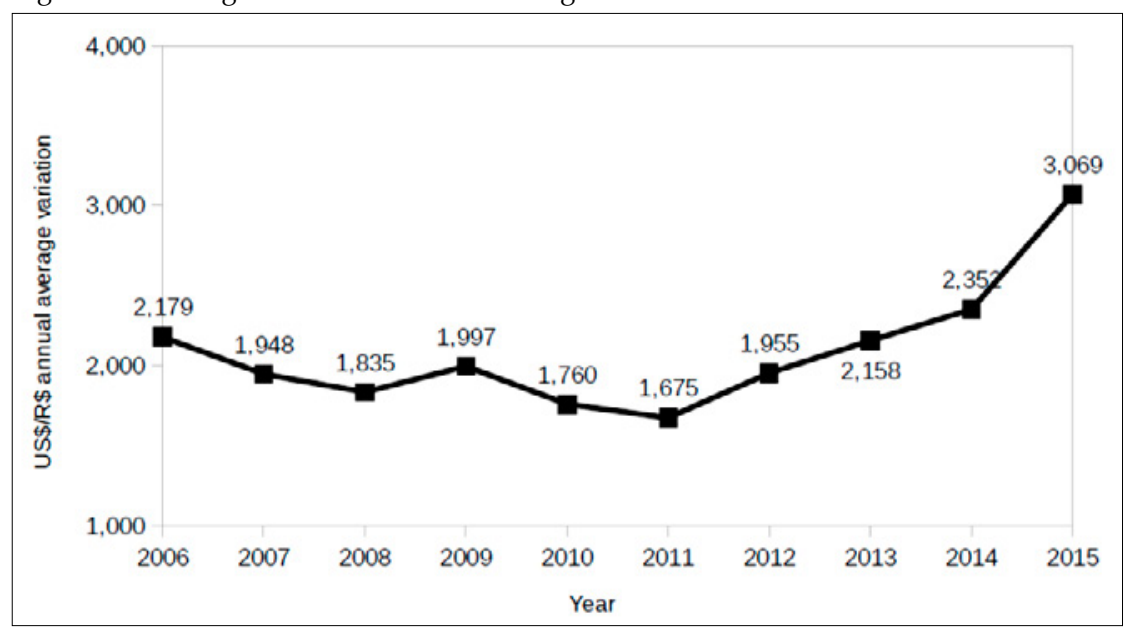

Figure 5 - Sixteen most abundant species in Brazilian (BR) and Ceará state (CE) marine ornamental exports from 2006 to August 2015.

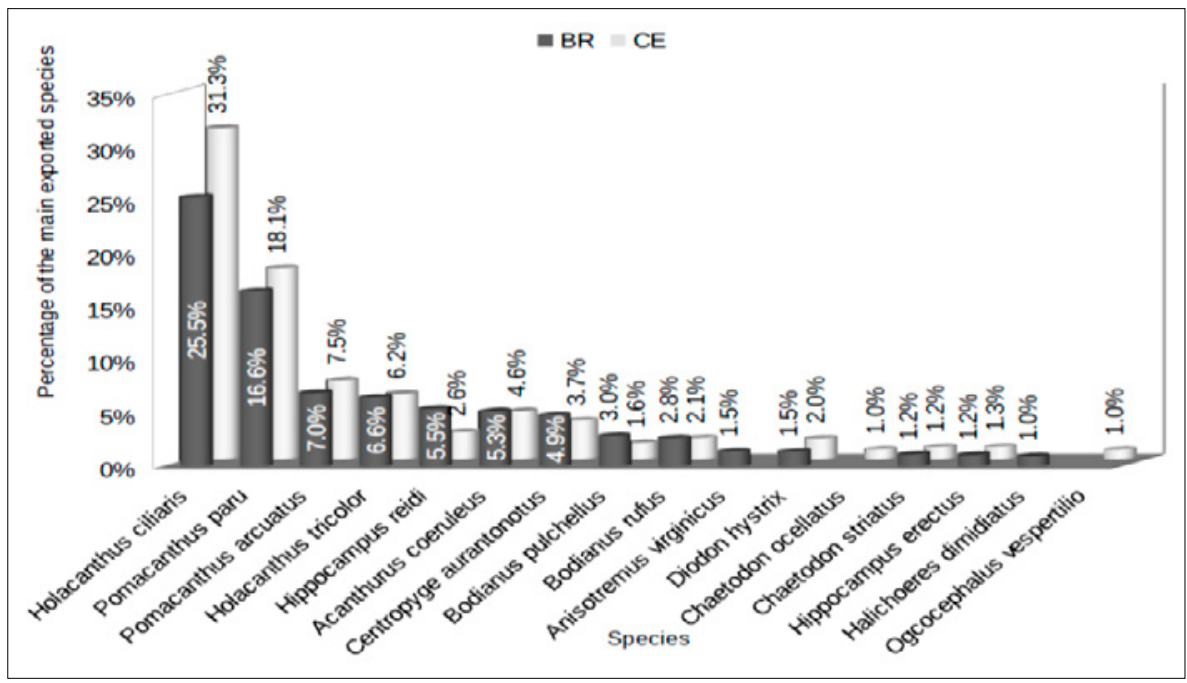

During the studied period, Brazil exported marine aquarium fish to 37 countries (Table II) and Japan, USA and Hong Kong were by far the main destination - as Sri Lanka and France imported less than 1\%, respectively, of the Brazilian and Ceará state's trade volume, their participation were not graphically expressed (Figure 6). 
Table II - Percentage participation of importing countries in the Brazilian and Ceará state's marine ornamental fish exports.

\begin{tabular}{|c|c|c|}
\hline \multirow{2}{*}{ Buyer countries } & \multicolumn{2}{|c|}{ Exporter (\%) } \\
\hline & Brazil & Ceará state \\
\hline Argentina & 0.17 & - \\
\hline Austria & 0.11 & 0.16 \\
\hline Bahrain Island & 0.04 & - \\
\hline Belgium & 0.38 & 0.11 \\
\hline Canada & 2.84 & 3.11 \\
\hline China & 0.20 & 0.23 \\
\hline Denmark & 0.23 & 0.18 \\
\hline Ecuador & 0.01 & 0.01 \\
\hline France & 1.10 & 0.11 \\
\hline Germany & 1.96 & 2.08 \\
\hline Greece & 0.10 & 0.15 \\
\hline Hong Kong & 21.32 & 18.21 \\
\hline Hungary & 0.12 & - \\
\hline Indonesia & 0.10 & 0.15 \\
\hline Israel & 0.73 & 0.39 \\
\hline Italy & 1.62 & 1.11 \\
\hline Japan & 24.95 & 30.64 \\
\hline Malaysia & 1.00 & 1.01 \\
\hline Netherlands & 2.58 & 2.23 \\
\hline New Zealand & 0.01 & 0.02 \\
\hline Norway & 0.02 & - \\
\hline Peru & 0.10 & 0.14 \\
\hline Poland & 0.07 & - \\
\hline Portugal & 0.06 & 0.02 \\
\hline Singapore & 3.21 & 2.19 \\
\hline South Africa & 0.07 & - \\
\hline South Korea & 1.81 & 2.18 \\
\hline Spain & 0.39 & 0.01 \\
\hline Sri Lanka & 0.81 & 1.08 \\
\hline Sweeden & 0.03 & - \\
\hline Switzerland & 0.07 & - \\
\hline Taiwan & 5.99 & 7.29 \\
\hline Thailand & 1.62 & 1.58 \\
\hline Turkey & 0.04 & 0.05 \\
\hline United Arab Emirates & 0.10 & 0.02 \\
\hline United Kingdom & 3.82 & 4.04 \\
\hline USA & 22.18 & 21.49 \\
\hline Total of exports & 25,295 & 17,61 \\
\hline
\end{tabular}

Figure 6-Relative participation of the fifteen most representative marine ornamental fish importers from Brazil (BR) and Ceará state (CE), based on the number of total exports.

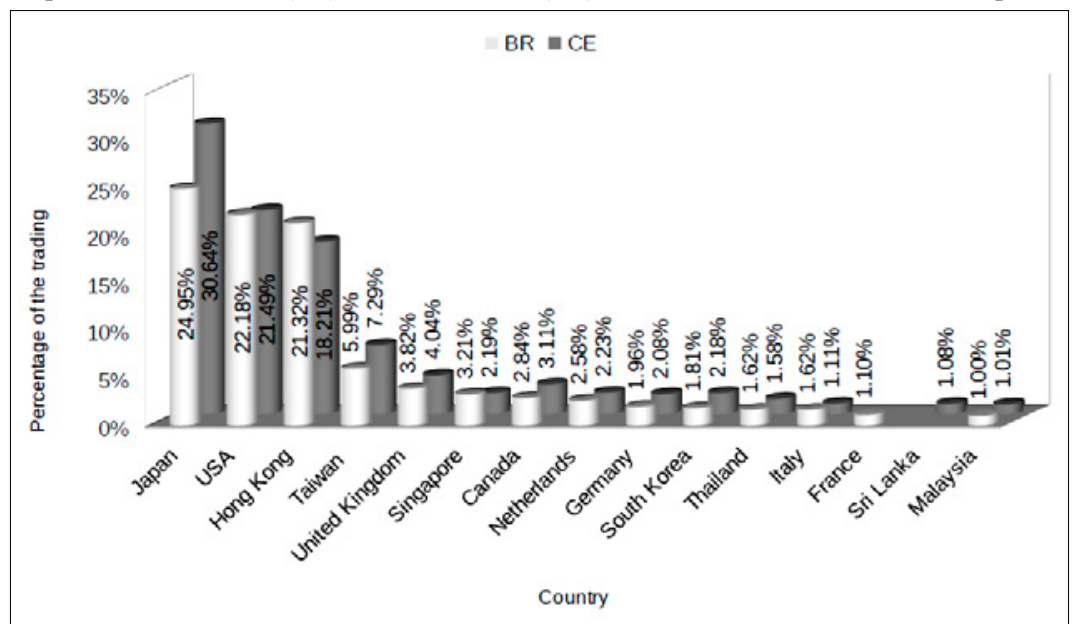


One-way-ANOVA showed seasonal differences within Brazilian $(\mathrm{F}=4.8029, \mathrm{p}=$ $0.0071)$ and Ceará state $(\mathrm{F}=4.4665, \mathrm{p}=0.0099)$ exports $-\mathrm{Fc}=2.9011, \mathrm{a}=0.05, \mathrm{df}=3-$, while Tukey HSD pairwise comparisons identified significantly different means in both Brazilian and Ceará state's trade (Figure 7).

Figure 7 - Percentage of exported specimens distributed throughout the seasons in the Northern Hemisphere. Error bars represent standard deviations and lower case letters refers to differences between winter and summer (a) and spring and summer (b) in both Brazilian and Ceará state exports, according to Tukey HSD.

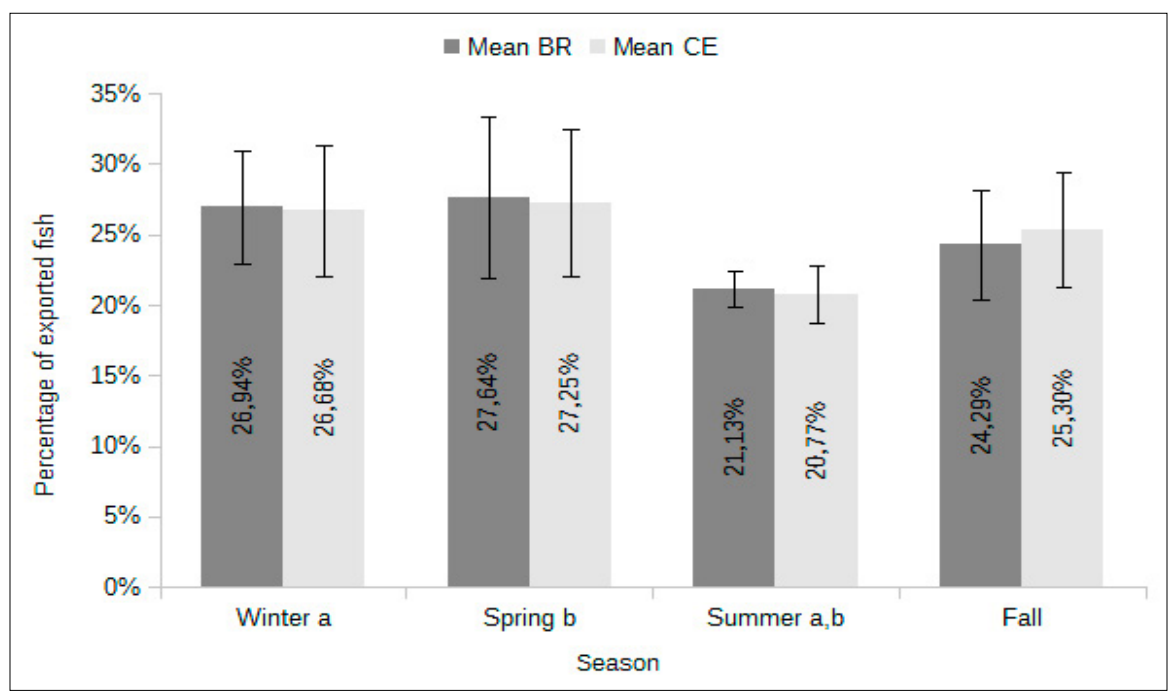

\section{DISCUSSION}

Although six other Brazilian states contribute for the total of marine aquarium fish export, Ceará offers privileged diving conditions (Pantalena, 2017) - which greatly improves ornamental fish harvesting - and has been considered the main trading center of the activity (Nottingham et al., 2000; Monteiro-Neto et al., 2003; Nottingham et al., 2005a).

The strong influence of Ceará state in the Brazilian international commerce becomes clear when their absolute numbers of exported individuals are brought together in a conjunct analysis. Most of the volume traded by the former is represented by the later and the same declining pattern of commerced individuals can be observed in both cases. Leal et al. (2016) also observed decreasing trends in Brazilian exports to Europe from ca. 282,000€ in 2000 to ca. $52,500 €$ in 2011.

Results also showed that the range of exported species decreased gradually until the end of the monitored period, when it reached solely half of what it used to be. If the quantity of specimens had increased while the variety of species had diminished along the time, one could think that efforts were then concentrated in a fewer number of species due to scarcity of the originally targeted species, or that there were changes in market demands. But it was not the case, such loss of diversity was probably a consequence of the diminishing number of exported specimens - the lower the amount of exported individuals, the lower is the probability of a larger number of species to be covered. 
These retractions in the number of exported specimens and variety of commerced species frustrated previous predictions of growth for the activity in Brazil (Monteiro-Neto et al., 2003) and unfortunately may be a sign of cumulative unsustainable fishery practices and/or economic adversities. According to marine ornamental fish exporters from Ceará state, such declining patterns had three main causes: (a) high-priced supplies, (b) unfavorable US Dollar exchange rates and (c) excessive regulation (e.g. export quotas) and bureaucracy to export the organisms - the latter, associated with legal changes, was also corroborated by Leal et al. (2016).

However, some of these allegations can be refuted. If on one hand oscillations of the US currency exchange rate (from 2006 to 2010) may result in expensive imported matters, on the other hand it will additionally rise profits obtained from fish exports. In the same way, when this rate drops, export profits are reduced, as well as the prices of imported supplies. Later, from 2011 to 2015, US Dollar exchange rate increased steeply and, thus, probably created a favorable scenario for exports. Maybe, the allegation of high-priced essential inputs harming exports does make sense when referred solely to non-imported products, associated with lower exchange rates.

Regarding the export quotas, traders have been trying to increase the established limits, under the allegation that the numbers were arbitrarily set, without any scientific support, and that those limits only harm exporters, since they are not applied to domestic wholesalers and retailers. Nevertheless, export quotas were established after a hard effort towards the conciliation of sustainability and economic viability and, therefore, quantities were determined by means of a criteria matrix and based on the amount of specimens exported in Ceará - the leading Brazilian exporting state (Nottingham et al., 2005a). However, flaws exist and must be corrected: quotas are not applied to collection but only to exports and, so, overtaken individuals can be freely commerced inside the country.

One odd example of how seriously such flaw can impact ornamental fish populations is concerning seahorses trade. According to Brazilian norms (IN IBAMA 202/08), Hippocampus reidi (Appendix II - CITES and Data Deficient status - The IUCN Red List of Threatened Species), and H. erectus (Appendix II - CITES and Vulnerable status - The IUCN Red List of Threatened Species) have the lowest export limits: 250 exported individuals/ enterprise/year, each. In the meanwhile, hundreds of them are captured without any restrictions to supply domestic marine aquarium trade or dried for magic-religious, medical and curio purposes (Rosa et al., 2011). In order to be more efficient, the system of quotas should focus on the origin of the chain (harvesting activities), instead of solely on exports.

Although some authors estimated the presence of 120 and 109 marine native fish species in Brazilian and Ceará state trade, respectively (Monteiro-Neto et al., 2003; Gasparini et al., 2005), the current numbers are slightly higher, since 136 species are reported here in Brazilian and 122 in Ceará state exports. Nearly 23\% of these species occurred in all years analyzed $(\mathrm{FO}=100 \%)$, what indicates their constant participation and may suggest their great importance to the activity. However, if just FO was considered as a criterion to evaluate the importance of species to the trade, it may magnify the participation of species that occur in small quantities but are very often recorded.

Hence, the abundance of specimens of each single species was also recorded as another criterion to evaluate individual contributions. However, \%Num by itself would overestimate the participation of organisms that occur just once, but in great quantities.

Thus, the observation of these two criteria altogether intends to compensate biases caused by analysis based exclusively on either FO or \% Num. So, as the top 16 most 
abundant species were also very often in the trade, they were considered the most important exported fish species along the last decade. Similarly, Rhyne et al. (2014) observed that only a small part of the total number of exported species $(\sim 15 \%)$ is handled in large volumes (85\%).

The identification of pomacanthids (H. ciliaris, H. tricolor, P. paru, P. arcuatus and C. aurantonotus) as the most representative group in the Brazilian marine ornamental industry had already been reported (Nottingham et al., 2000; Monteiro-Neto et al., 2003; Gasparini et al., 2005; IBAMA, 2008) and made Brazilian authorities set them substantially higher export quotas compared to the other exploited species, in an attempt to conciliate social, economic and environmental interests (Nottingham et al., 2005a). Furthermore, the higher numbers of exported $H$. ciliaris presented here reflect their great abundance in Ceará state waters and also is an evidence of a significant demand for the species in the international market. On the other hand, a minor participation of H. tricolor and C. aurantionotus in the trade is probably associated with their scarcity in Ceará coast (and presumable collection in other Brazilian states to be later exported from there) - according to Ferreira et al., (2004), low quantities of traded C. aurantionotus are influenced by harvesting difficulties, because in Brazilian Northeastern coast flameback angelfish are found solely on deep reefs. A similar situation is detected for other species, such as B. pulchellus, which is not so common at Ceará state, but is mostly harvest in other Brazilian states and then exported from there.

The presence of $A$. coeruleus among the most important Brazilian traded aquarium species had already been reported (Monteiro-Neto et al., 2003; Gasparini et al., 2005) and the much higher number of longsnout $(H$. reidi) compared to lined (H. erectus) seahorses, may have two complementary causes: (a) most of the seahorses exported as H. erectus were in fact $H$. reidi, that used to be misidentified to double the given quota (Monteiro-Neto et al., 2003; Rosa et al., 2011) - however, along the last decade the number of traded H. erectus decreased significantly, probably because exporters became more cautious due to reinforced inspections of the Brazilian environmental authorities -, and (b) captive bred $H$. reidi began to be exported under extra quotas, adding much more individuals to those exclusively wild-caught (Hora \& Joyeux, 2009; IBAMA, 2009).

It is also important to notice that 255,658 is the number of effectively exported pomacanthids, but considering a mortality rate of 10,9\% (Nottingham et al., 2005b) and assuming that other angelfish specimens are harvested to supply domestic trade (despite being a much less expressive commerce), it can be assumed that more than 283,525 individuals were wild-caught in the last 10 years. Furthermore, collection for ornamental purposes are not the only threat towards marine fish. Pomacanthids (as well as some acanthurids and chaetodontids) are by-catch in trap and gillnet lobster fisheries (Ivo et al., 1996), shrimp trawling (Braga et al., 2001) and fish traps (Feitosa et al., 2008) in Brazil and, so, it is difficult to address how deep ornamental fish are being negatively impacted by the marine aquarium industry, specially in face of the paucity of scientific information regarding their population biology.

Moreover, it is known that grazer fishes are an important biotic factor regulating the structure of benthic communities in reef ecosystems and tropical rocky shores, and their exclusion reduce the resilience of coral reefs in face of different kinds of disturbances, besides influencing abundance, distribution and shape of sponges (Batista et al., 2012). Hence, the indiscriminate removal of pomacanthids from reef ecosystems may result in serious negative reflexes on community structure and the impacts caused to the coral reefs can be greater than angelfishes' abundance suggest (Gasparini et al., 2005). In fact, the 
potential impact of fisheries targeting aquarium reef fish in Brazil is also difficult to be evaluated because little is known about the distribution of this type of fishing effort throughout the country, and the complete level of threat to reef fish is hard to be assessed (Floeter et al., 2006).

The ecological effects of fisheries on pomacanthid populations are poorly known. Angelfishes may occupy a variety of trophic niches (Konow \& Bellwood, 2011), and are typically considered spongivorous in Brazil - as in the Caribbean (Hourigan et al., 1989; Hill, 1998; Andréa et al., 2007; Reis et al., 2012) -, and, so, experiments involving their removal from reefs have resulted in decreasing coral covers caused by sponge overgrowth (Hill, 1998). However, some other works report ontogenetic variations in the foraging habit of Brazilian pomacanthids (Sazima et al., 1999) and the prevalence of algae rather than sponge in their gut contents, according to local food availability and other factors (Batista et al., 2012; Reis et al., 2012). Hence, overexploitation of pomacanthids and some herbivorous species (e.g. the strict turf algae feeder surgeonfish A. coeruleus - Ferreira et al., 2004) could increase macroalgal abundance and therefore promote coral suppression by intense competition - on healthy reefs, for instance, both the establishment and survival of corals depend on high rates of herbivory to suppress seaweeds growth, reducing competition with cnidarians (Mumby, 2006; Box \& Mumby, 2007; Hughes et al., 2007; Mumby \& Harborne, 2010; Comeros-Raynal et al., 2012; Bonaldo \& Hay, 2014).

Despite the potential damages the activity may cause to marine fish populations and ecosystems, marine aquarium trade can improve the economy of source habitats, promote conservation initiatives, and educate people and rise awareness about the crisis coral reefs are facing nowadays (Bellwood et al., 2004; Rhyne et al., 2012; Rhyne et al., 2014). In Ceará state, for instance, marine fish collection is an important source of income for many communities and some families depend exclusively on ornamental harvesting to survive (Nottingham et al., 2005b). Thus, Brazilian marine fish trade shall not be forbidden, but stimulated on sustainable basis, by means of conservation practices, in order to take back its growing expectations.

The implementation of conservation actions must take into account many characteristics of the targeted species, whose protection is imperative for both economic and ecological reasons - which include: (a) reproductive and feeding behavior (ComerosRaynal et al., 2012), (b) mating systems (Moyer et al., 1983; Hourigan \& Kelley, 1985; Feitosa et al., 2015) and (c) spawning strategies (Nottingham et al., 2003; Feitosa et al., 2015).

Some ecosystem-based management initiatives, such as the implementation of Marine Protected Areas - MPA, Fish Replenishment Areas, establishment of a limited entry program for aquarium fishery and a number of other actions, have promoted recovery of stocks of heavily exploited marine aquarium species (e.g. the yellow tang Zebrasoma flavescens - Friedlander, 2001; Tissot et al., 2004; Tissot et al., 2009; Stevenson \& Tissot, 2013; Rhyne et al., 2014). Such initiatives, instead of preserving a particular species, aim not only the protection of the whole ecosystem but also assure the continuity of inter and intraspecific associations, including the safety of spawning aggregation sites (Friedlander, 2001; Gerhardinger et al., 2009; Comeros-Raynal et al., 2012). However, unfortunately, in Ceará state the creation of a MPA was not effective to prevent the indiscriminate collection of marine ornamental fish (Nottingham et al., 2000; Soares et al., 2011).

In the beginning of the last decade, Brazilian exports of marine ornamental fish involved just 19 countries (Monteiro-Neto et al., 2003), but in more recent years this number almost doubled, as a direct consequence of globalization (Rhyne \& Tlusty, 2012). Another 
aspect of the international market that presented significant changes was regarding the main importing countries. According to Monteiro-Neto et al. (2003), Brazil used to export marine aquarium fish mostly, in decreasing order, to the USA, Italy, Japan, Germany, China, Taiwan and others (including some other European countries). Nevertheless, current Brazilian exports are mainly driven to Asian countries (specially Japan, Hong Kong and Taiwan), displacing the USA from the top leading importer position. However, such change does not mean that the USA reduced imports of marine ornamental fish - but quite the opposite, as it is still the main destination of most of the marine aquarium organisms traded worldwide (Rhyne \& Tlusty, 2012; Rhyne et al., 2012; Rhyne et al., 2014) -, what happened was that Brazilian traders seem to have found more marketable opportunities in Asia than in North America.

Although Monteiro-Neto et al. (2003) observed the highest export numbers in Ceará state during the Northern Hemisphere coldest months, when hobbyists spend more time taking care of their home aquaria, in the present work pairwise comparisons could not confirm such suggestion since no significant difference was detected among winter, spring or fall. On the other hand, summer presented the lowest mean of exported specimens significantly different from winter and spring, but not from fall -, which may have been caused by intense windy seasons in Northeastern Brazil.

Seasonal displacements of the Intertropical Convergence Zone (ITCZ) intensify the power of trade winds in Northeast Brazil, specially in August-September - sometimes also coinciding with the arrival of strong swell waves (September-October) along the coast -, thus posing a real danger for fishing boats and producing low-visibility dive conditions (Silva, 2003; Farias, 2008; Pantalena, 2017). Indeed, during windy seasons in Ceará state many vessels focused on distinct targeted species stay anchored until the end of the unfavorable weather conditions.

Hence, if catches and then exports (since they occur just a few days after harvesting - Nottingham et al., 2005b) decrease in Ceará state in the second half of the year, the Brazilian trade numbers are significantly brought downwards due to the high influence of the former on the overall commerce. Unfortunately, the present work could not examine the direct relationship between harvesting and windy season in Northeast Brazil, since data analyzed here were concerning exports only and not regarding catches. Nottingham et al. (2000) addressed the collecting of marine ornamental fish in Ceará state but their data do not allow comparisons throughout the whole year. Thus, this subject still needs further investigation.

Acknowledgments - The authors would like to thank to D. P. Lopes (IBAMA/CE), J. R. O. César (DEP/UFC), M. A. A. Furtado-Neto (Labomar/UFC); D. S. Garcez (Labomar/UFC) and J. E. P. Freitas (Post-Doctoral scholar/UFC) for helpful comments on previous versions of the present work; the anonymous referees for criticism to improve the manuscript; and, specially, H. A. C. Ramos (IBAMA/MMA) for providing access to the data analyzed here.

\section{REFERENCES}

Andréa, B.R.; Batista D.; Sampaio, C.L.S. \& Muricy, G. Spongivory by juvenile angelfish (Pomacanthidae) in Salvador, Bahia State, Brazil, pp. 131-137, in: Custodio, M.R.; LôboHajdu, G.; Hajdu, E. \& Muricy, G. (eds.), Porifera Research: Biodiversity, innovation and sustainability. Museu Nacional, 684 p., Rio de Janeiro, 2007. 
Batista, D.; Muricy, G.R.S.; Andréa, B.R. \& Villaça, R.C. High intraspecific variation in the diet of the french angelfish Pomacanthus paru in the South-Western Atlantic. Braz. J. Oceanogr., v. 60, n. 3, p. 449-454, 2012.

Bellwood, D.R.; Hughes T.P.; Folke, C. \& Nystro, M. Confronting the coral reef crisis. Nature, v. 429, p. 827-833, 2004.

Bonaldo, R.M. \& Hay, M.E. Seaweed-coral interactions: variance in seaweed allelopathy, coral susceptibility, and potential effects on coral resilience. PLoS ONE, v. 9, n. 1, p. e85786, 2014.

Box, S.J. \& Mumby, P.J. Effect of macroalgal competition on growth and survival of juvenile Caribbean corals. Mar. Ecol. Prog. Ser., v. 342, p. 139-149, 2007.

Braga, M.S.C.; Salles, R. \& Fonteles-Filho, A.A. Ictiofauna acompanhante da pesca de camarões com rede-de-arrasto na zona costeira do município de Fortaleza, estado do Ceará, Brasil. Arq. Cienc. Mar, v. 34, p. 49-60, 2001.

Bruckner, A.W. The importance of the marine ornamental reef fish trade in the wider Caribbean. Rev. Biol. Trop., v. 53, n. 1, p. 127-138, 2005.

Comeros-Raynal, M.T.; Choat, J.H.; Polidoro, B.A.; Clements, K.D.; Abesamis, R.; Craig, M.T.; Lazuardi, M.E.; McIlwain, J.; Muljadi, A.; Myers, R.F.; Nañola-Junior, C.L.; Pardede, S.; Rocha, L.A.; Russell, B.; Sanciangco, J.C.; Stockwell, B.; Harwell, H. \& Carpenter, K.E. The Likelihood of Extinction of Iconic and Dominant Herbivores and Detritivores of Coral Reefs: The Parrotfishes and Surgeonfishes. PLoS ONE, v. 7, n. 7, p. e39825, 2012.

Farias, E.G.G. Aplicação de técnicas de geoprocessamento para a análise da evolução da linha de costa em ambientes litorâneos do estado do Ceará. Dissertação de Mestrado, Programa de Pósgraduação em Ciências Marinhas Tropicais, Universidade Federal do Ceará, 109 p., Fortaleza, 2008.

Feitosa, C.V.; Ferreira, B.P. \& Araújo, M.E. A rapid newmethod for assessing sustainability of ornamental fish by-catch from coral reefs. Mar. Fresh. Res., v. 59, p. 1092-1100, 2008.

Feitosa, C.V.; Marques, S.; Araújo, M.E. \& Ferreira, B.P. Reproduction of French angelfish Pomacanthus paru (Teleostei : Pomacanthidae) and implications for management of the ornamental fish trade in Brazil. Mar. Fresh. Res., v. 67, n. 5, p. 586-593, 2015.

Ferreira, C.E.L.; Floeter, S.R.; Gasparini, J.L.; Ferreira, B.P. \& Joyeux, J.C. Trophic structure patterns of Brazilian reef fishes: a latitudinal comparison. J. Biogeogr., v. 31, p. 1093-1106, 2004.

Floeter, S.R.; Halpern, B.S. \& Ferreira, C.E.L. Effects of fishing and protection on Brazilian reef fishes. Biol. Conserv., v. 128, p. 391-402, 2006.

Friedlander, A.M. Essential fish habitat and the effective design of marine reserves: application for marine ornamental fishes. Aquarium Sci. Conserv., v. 3, p. 135-150, 2001.

Froese, R. \& Pauly, D (eds). FishBase, version 02/2017. 2017. Available at: <http:/ /www. fishbase.org/>. Accessed on 23 mar. 2017.

Gasparini, J.L.; Floeter, S.R.; Ferreira, C.E.L. \& Sazima, I. Marine ornamental trade in Brazil. Biodivers. Conserv., v. 14, p. 2883-2899, 2005.

Gerhardinger, L.C.; Hostim-Silva, M.; Medeiros, R.P.; Matarezi, J.; Bertoncini, A.A.; Freitas, M.O. \& Ferreira, B.P. Fishers' resource mapping and goliath grouper Epinephelus itajara (Serranidae) conservation in Brazil. Neotrop. Ichthyol., v. 7, n. 1, p. 93-102, 2009. 
Guimarães, N. Por uma sociologia do desemprego. Rev. Bras. Cien. Soc., São Paulo, v. 25, n. 74, 2010. Disponível em: www.scielo.br. Acesso em: 11 mar. 2011.

Hammer, Ø., Harper, D.A.T. \& Ryan, P.D. PAST: Paleontological statistics software package for education and data analysis. Palaeontol. Electron., v.4, n.1, 9 p., 2001. Available at http:/ / palaeo-electronica.org/2001_1/past/issue1_01.htm]. Last access on 20/03/2017.

Hill, M.S. Spongivory on Caribbean reefs releases corals from competition with sponges. Oecologia, v. 17, n. 1, p. 143-150, 1998.

Hora, M.S.C \& Joyeux, J.C. Closing the reproductive cycle: Growth of the seahorse Hippocampus reidi (Teleostei, Syngnathidae) from birth to adulthood under experimental conditions. Aquaculture, v. 292, p. 37-41, 2009.

Hourigan, T. \& Kelley, C. Histology of the gonads and observations on the social behavior of the Caribbean angelfish Holacanthus tricolor. Mar. Biol., v. 88, n. 3, p. 311-322, 1985.

Hourigan, T.F.; Stanton, F.G.; Motta, P.J.; Kelley, C.D. \& Carlson, B. The feeding ecology of three species of Caribbean angelfishes (family Pomacanthidae). Environ. Biol. Fish., v. 24, n. 2, p. 105-116, 1989.

Hughes, T.P.; Rodrigues, M.J; Bellwood, D.R.; Ceccarelli, D.; Hoegh-Guldberg, O.; McCook, L.; Moltschaniwskyj, N.; Pratchett, M.S.; Steneck, R.S. \& Willis, B. Phase shifts, herbivory and the resilience of coral reefs to climate change. Curre. Biol., v. 7, n. 4, p. 360-365, 2007.

IBAMA. Diagnóstico geral das práticas de controle ligadas a exploração, captura, comercialização, exportação e uso de peixes para fins ornamentais e de aquariofilia. Instituto Brasileiro do Meio Ambiente e dos Recursos Naturais Renaváveis, 217 p., Brasília, 2008.

IBAMA. Proposta de Plano de Gestão para o Uso Sustentável dos Cavalos-Marinhos do Brasil. Instituto Brasileiro do Meio Ambiente e dos Recursos Naturais Renaváveis, 104 p., Brasília, 2009.

Ivo, C.T.C.; Santiago, M.E \& Monteiro-Neto, C. Fauna acompanhante na pesca das lagostas Panulirus argus (Latreille) e Panulirus laevicauda (Latreille), no estado do Ceará, Brasil. Arq. Cienc. Mar, v. 30, p. 41-47, 1996.

Konow, N. \& Bellwood, D.R. Evolution of high trophic diversity based on limited functional disparity in the feeding apparatus of marine angelfishes (f. Pomacanthidae). PLoS ONE, v. 6, n. 9, p. e24113, 2011.

Leal, M.C.; Vaz, M.C.M.; Puga, J.; Rocha, R.J.M.; Brown, C.; Rosa, R. \& Calado, R. Marine ornamental fish imports in the European Union: an economic perspective. Fish Fish., v. 17, n. 2, p. 459-468, 2016.

Monteiro-Neto, C.; Cunha, F.E.A.; Nottingham, M.C.; Araújo, M.E.; Rosa, I.L. \& Barros, G.M.L. Analysis of the marine ornamental fish trade at Ceará State, Northeast Brazil. Biodivers. Conserv., v. 12, p. 1287-1295, 2003.

Moyer, J.T.; Thresher, R.E. \& Colin, P.L. Courtship, spawning and inferred social organization of American angelfishes (Genera Pomacanthus, Holacanthus and Centropyge; Pomacanthidae). Environ. Biol. Fish., v. 9, n. 1, p. 25-39, 1983.

Mumby P.J. \& Harborne, A.R. Marine Reserves Enhance the Recovery of Corals on Caribbean Reefs. PLoS ONE, v. 5, n. 1, p. e8657, 2010. 
Mumby, P.J. The impact of exploiting grazers (scaridae) on the dynamics of caribbean coral reefs. Ecol. Appl., v. 16, n. 2, p. 747-769, 2006.

Nottingham, M.C.; Barreto, L.M.; Araújo, M. E.; Monteiro-Neto, C.; Cunha, F.E.A.; Rosa, I.M.L. \& Alencar, C.A.G. A explotação de peixes ornamentais marinhos no estado do Ceará, Brasil: capturas e manutenção nas empresas e exportação. Bol. Tec. Cient. CEPENE, v. 13, n. 1 , p. 53-73, 2005b.

Nottingham, M.C.; Barros, G.M.L.; Araújo, M.E.; Rosa, I.M.L.; Ferreira, B.P. \& Mello, T.R.R. $\mathrm{O}$ ordenamento da explotação de peixes ornamentais marinhos no Brasil. Bol. Tec. Cient. CEPENE, v. 13, n. 1, p. 75-107, 2005a.

Nottingham, M.C.; Cunha, F.E.A. \& Monteiro-Neto, C. Captura de peixes ornamentais marinhos no estado do Ceará. Arq. Cienc. Mar, v. 33, p.113-118, 2000.

Nottingham, M.C.; Silva, J.R.F. \& Araújo, M.E. Morphology and histology of the testicles of queenangelfish Holacanthusciliaris (Linnaeus, 1758) (Teleostei:Perciformes:Pomacanthidae). Arq. Cienc. Mar, v. 36, p. 89-94, 2003.

Pantalena, A. F. Mergulho recreativo na região metropolitana de Fortaleza (NE, Brasil): subsídios para o desenvolvimento sustentável. Tese de Doutorado, Programa de Pós-graduação em Ciências Marinhas Tropicais, Universidade Federal do Ceará, 130 p., Fortaleza, 2017.

Reis, F.; Moraes, F.; Batista, D.; Villaça, R.; Aguiar A. \& Muricy, G. Diet of the queen angelfish Holacanthus ciliaris (Pomacanthidae) in São Pedro e São Paulo Archipelago, Brazil. J. Mar. Biol. Ass. U. K, v. 93, n. 2S, p. 453-460, 2012.

Rhyne, A.L. \& Tlusty, M.F. Trends in the marine aquarium trade: the influence of global economics and technology. Aquac. Aquar. Conserv. Legis., v. 5, p. 99-102, 2012.

Rhyne, A.L.; Tlusty, M.F. \& Kaufman, L. Is sustainable exploitation of coral reefs possible? A view from the standpoint of the marine aquarium trade. Curr. Opin. Environ. Sustain., v. 7, p.101-107, 2014.

Rhyne, A.L.; Tlusty, M.F.; Schofield, P.J.; Kaufman, L.; Morris-Junior, J.A. \& Bruckner, A.W. Revealing the appetite of the marine aquarium fish trade: the volume and biodiversity of fish imported into the United States. PLOS ONE, v. 7, n. 5, p. e35808, 2012.

Rocha, L.A. \& Rosa, R.S. Halichoeres brasiliensis (Bloch, 1791), a valid wrasse species (Teleostei: Labridae) from Brazil, with notes on the Caribbean species Halichoeres radiatus (Linnaeus, 1758). Aqua, J. Ichthyol. Aquat. Biol., v. 4, p.161-166, 2001.

Rocha, L.A. Mitochondrial DNA and color pattern variation in three western Atlantic Halichoeres (Labridae), with the revalidation of two species. Copeia, v. 4, p.770-782, 2004.

Rosa, I.L.; Oliveira, T.P.R.; Osório, F.M.; Moraes, L.E.A.; Castro, L.; Barros, G.M.L. \& Alves, R.R.N. Fisheries and trade of seahorses in Brazil: historical perspective, current trends, and future directions. Biodivers. Conserv., v. 20, n. 9, p. 1951-1971, 2011.

Sazima, I.; Moura, R.L. \& Sazima, C. Cleaning Activity of Juvenile Angelfish, Pomacanthus paru, on the reefs of the Abrolhos Archipelago, western South Atlantic. Environ. Biol. Fish., v. 56, n. 4, p. 399-407, 1999.

Silva, G.R. Características de vento da região nordeste: análise, modelagem e aplicações para projetos de centrais eólicas. Dissertação de Mestrado, Programa de Pós-graduação em Engenharia Mecânica, Universidade Federal de Pernambuco, 131 p., Recife, 2003. 
Soares, M.O.; Paiva, C.C.; Freitas, J.E.P \& Lotufo, T.M.C. Gestão de unidades de conservação marinhas: o caso do Parque Estadual Marinho da Pedra da Risca do Meio, NE - Brasil. Rev. Gestão Costeira Integr., v. 11, n. 2, p. 257-268, 2011.

Stevenson, T. C. \& Tissot, B. N. Evaluating marine protected areas for managing marine resource conflict in Hawaii. Mar. Policy, v. 39, p. 215-223, 2013.

Stevenson, T. C.; Tissot, B. N. \& Dierking, J. Fisher behaviour influences catch productivity and selectivity in West Hawaii's aquarium fishery. J. Mar. Sci., v. 68, n. 5, p. 813-822, 2011.

Tissot, B.N., Best, B. A, Borneman, E., Bruckner, A. W., Cooper, C.H., D’Agnes, H., Fitzgerald, T.P., Leland, A., Lieberman, S., Amos, A.M. Sumaila, R., Telecky, T.M., McGilvray, F., Plankis, B.J., Rhyne, A.L., Roberts, G.G., Starkhouse, B., Stevenson, T.C. How U.S. ocean policy and market power can reform the coral reef wildlife trade. Mar. Policy, v. 34, p. 1385-1388, 2010.

Tissot, B.N.; Walsh, W.J. \& Hallacher, L.E. Evaluating effectiveness of a marine protected area network in West Hawai'i to increase productivity of an aquarium fishery. Pac. Sci., v. 58, n. 2, p. 175-188, 2004.

Tissot, B.N.; Walsh, W.J. \& Hixon, M.A. Hawaiian islands marine ecosystem case study: ecosystem and community-based management in Hawaii'. Coast. Manage., v. 37, n. 3, p. 255-273, 2009.

Wood, E. Collection of coral reeffish for aquaria: global trade, conservation issues and management strategies. Marine Conservation Society, 56 p., Ross-on-Wye, 2001. 